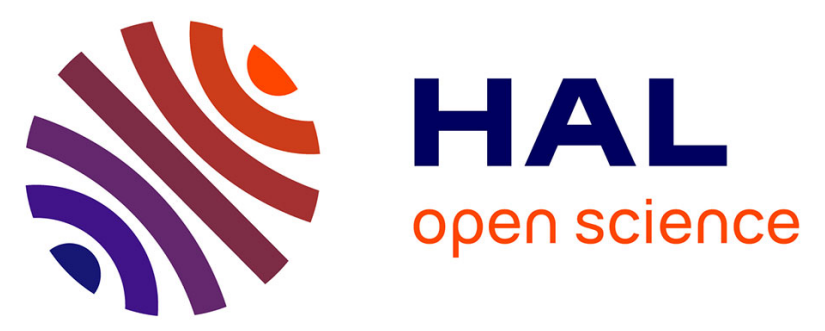

\title{
Impacts from urban water systems on receiving waters - How to account for severe wet-weather events in LCA?
}

Eva Risch, Johnny Gasperi, Marie-Christine Gromaire, Ghassan Chebbo, Sam Azimi, Vincent Rocher, Philippe Roux, Ralph K. Rosenbaum, Carole Sinfort

\section{- To cite this version:}

Eva Risch, Johnny Gasperi, Marie-Christine Gromaire, Ghassan Chebbo, Sam Azimi, et al.. Impacts from urban water systems on receiving waters - How to account for severe wet-weather events in LCA?. Water Research, 2017, 128, pp.412-423. 10.1016/j.watres.2017.10.039 . hal-01622102

\section{HAL Id: hal-01622102 \\ https://hal-enpc.archives-ouvertes.fr/hal-01622102}

Submitted on 16 May 2020

HAL is a multi-disciplinary open access archive for the deposit and dissemination of scientific research documents, whether they are published or not. The documents may come from teaching and research institutions in France or abroad, or from public or private research centers.
L'archive ouverte pluridisciplinaire HAL, est destinée au dépôt et à la diffusion de documents scientifiques de niveau recherche, publiés ou non, émanant des établissements d'enseignement et de recherche français ou étrangers, des laboratoires publics ou privés. 
Author-produced version of the article published in Water Research, 2017, N¹28, p.412-423.

The original publication is available at https://www.sciencedirect.com

Doi: 10.1016/j.watres.2017.10.039

Impacts from urban water systems on receiving waters - How to account for severe wet-weather events in LCA?

Eva Risch ${ }^{1}$, Johnny Gasperi ${ }^{2}$, Marie-Christine Gromaire ${ }^{3}$, Ghassan Chebbo $^{3}$, Sam Azimi ${ }^{4}$, Vincent Rocher ${ }^{4}$, Philippe Roux ${ }^{1}$, Ralph K. Rosenbaum ${ }^{1}$, Carole Sinfort ${ }^{1}$

${ }^{1}$ ITAP, Irstea, Montpellier SupAgro, Univ Montpellier, Montpellier, France

${ }^{2}$ Université Paris-Est, LEESU, UMR MA 102 - AgroParisTech, 94010 Créteil, France

${ }^{3}$ Université Paris-Est, LEESU, UMR MA 102 - AgroParisTech, 77455 Marne-la-Vallée, France

${ }^{4}$ SIAAP, Direction du Développement et de la Prospective, 92700 Colombes, France

E-mail contact: eva.risch@irstea.fr

\section{Abstract}

Sewage systems are a vital part of the urban infrastructure in most cities. They provide drainage, which protects public health, prevents the flooding of property and protects the water environment around urban areas. On some occasions sewers will overflow into the water environment during heavy rain potentially causing unacceptable impacts from releases of untreated sewage into the environment. In typical Life Cycle Assessment (LCA) studies of urban wastewater systems (UWS), average dry-weather conditions are modelled while wet-weather flows from UWS, presenting a high temporal variability, are not currently accounted for. In this context, the loads from several storm events could be important contributors to the impact categories freshwater eutrophication and ecotoxicity. In this study we investigated the contributions of these wet-weather-induced discharges relative to average dry-weather conditions in the life cycle inventory for UWS. In collaboration with the Paris public sanitation service (SIAAP) and Observatory of Urban Pollutants (OPUR) program researchers, this work aimed at identifying and comparing contributing flows from the UWS in the Paris area by a selection of routine wastewater parameters and priority pollutants. This collected data is organized according to archetypal weather days during a reference year. Then, for each archetypal weather day and its associated flows to the receiving river waters (Seine), the parameters of pollutant loads (statistical distribution of concentrations and volumes) were determined. The resulting inventory flows (i.e. the potential loads from the UWS) were used as LCA input data to assess the associated impacts. This allowed investigating the relative importance of episodic wet-weather versus 
Author-produced version of the article published in Water Research, 2017, №128, p.412-423.

The original publication is available at https://www.sciencedirect.com

Doi: 10.1016/j.watres.2017.10.039

"continuous" dry-weather loads with a probabilistic approach to account for pollutant variability within the urban flows. The analysis at the scale of one year showed that storm events are significant contributors to the impacts of freshwater eutrophication and ecotoxicity compared to those arising from treated effluents. At the rain event scale the wet-weather contributions to these impacts are even more significant, accounting for example for up to $62 \%$ of the total impact on freshwater ecotoxicity. This also allowed investigating and discussing the ecotoxicity contribution of each class of pollutants among the broad range of inventoried substances. Finally, with such significant contributions of pollutant loads and associated impacts from wetweather events, further research is required to better include temporally-differentiated emissions when evaluating eutrophication and ecotoxicity. This will provide a better understanding of how the performance of an UWS system affects the receiving environment for given local weather conditions.

Keywords: life cycle assessment; urban wastewater systems; wet-weather emissions; temporal variability; combined sewer overflows; stormwater

Abbreviations: $\mathrm{BOD}_{5}$, biochemical oxygen demand; $\mathrm{CSO}$, combined sewer overflows; LCA, life cycle assessment; LCI, life cycle inventory; LCIA, life cycle impact assessment; OPUR, Observatory of Urban Pollutants; SIAAP, Paris public sanitation service; UWS, urban wastewater systems; WFD, European Water Framework Directive; WWTP, wastewater treatment plants;

\section{Introduction}

Handling of water resources (scarcity and/or flooding) is needed for all types of catchments. With an ever increasing rate of urbanisation on a planetary scale, stormwater management has become a tremendous challenge and deals with pollution, additional stormwater and increased flooding.

Stormwater sewers are exclusively dedicated to the collection of stormwater whereas combined sewers also collect wastewater from domestic and/or industrial sources in an urban area. Sewers provide drainage, which protects public health, prevents the flooding of property and protects the water environment around urban areas. Usually combined systems are found in temperate - and to some extent subtropical - climates and are concentrated in North America, Canada, Europe, Australia and, to some extent, Japan. In these countries, combined sewer networks dominate the central and old parts of the large cities whereas separate systems exist in the new developments and suburbs (Hvitved-Jacobsen et al., 2010). 
Author-produced version of the article published in Water Research, 2017, N¹28, p.412-423.

The original publication is available at https://www.sciencedirect.com

Doi: 10.1016/j.watres.2017.10.039

During dry weather, the combined sewage collection system, which transports wastewater to the wastewater treatment plant, operates effectively. However, during a heavy rainstorm, extra stormwater gets into the sewage collection system through direct connections. This extra volume of water overloads the sewage collection system and raw untreated sewage overflows at several locations potentially causing impacts on the environment. Historically, sanitary and civil engineering have focused on handling the physical aspects of wet-weather (protection against flooding), omitting the eutrophication and ecotoxicity impacts of combined sewer overflows (CSO) and stormwater on receiving water ecosystems. It is well-known today that stormwater from urban and industrial areas and from roads constitutes one of the main transport mechanisms introducing non-point source pollutants into receiving waters (Pitt et al., 1995; Zgheib et al., 2011). This is why urban stormwater is currently the most significant pollution hazard for coastal waters downstream of densely urbanized areas with separate sewer systems such as the Southern California Bight (DiGiacomo et al., 2004; Schiff et al., 2000). There is a growing number of studies evaluating ecotoxicological impacts of urban wet-weather discharges (stormwater and CSO) on stream ecosystems using an array of tools (Angerville, 2009; Becouze-lareure et al., 2012; Gosset et al., 2016). In Europe, the implementation of the control policy of pollutants entering the receiving waters in the Water Framework Directive 2000/60/EC (WFD) in 2001, has led to increased research efforts to identify possible pollutant reduction measures. Given the lack of accurate and extensive data on the contamination by priority pollutants of urban flows which enter receiving waters, the Observatory of Urban Pollutants (OPUR) research programme has sought to investigate the production and transfer of pollutants in these flows, which include treated effluents from wastewater treatment plants; CSO discharges and untreated stormwater. This research has delivered data on the occurrence and concentration of priority pollutants listed in the WFD and additional pollutants -typically measured in urban stormwater- from both separate and combined sewers of the Greater Paris area (Gasperi et al., 2014, 2012; Zgheib, 2009; Zgheib et al., 2012). In parallel to the identification of pollutant flows, the need for holistic methods for the environmental assessment of water and wastewater systems was identified and Life Cycle Assessment (LCA) is now increasingly used as a promising approach (Loubet et al., 2014). Indeed, LCA enables the comparison of environmental performances of products or services, supporting decision-making by consumers, industries and governments. LCA in the context of urban wastewater systems (UWS) aim to provide quantitative information to policy makers on UWS environmental profiles, hot spots, and forecasting scenarios that can involve (depending on the chosen goal): (i) change or improvement of a technology (e.g., construction of a new treatment plant or an increase in the connection rate of a waste water collection system), (ii) change of water 
Author-produced version of the article published in Water Research, 2017, №128, p.412-423.

The original publication is available at https://www.sciencedirect.com

Doi: 10.1016/j.watres.2017.10.039

resources (e.g., water abstraction from another river, wastewater release into the sea) and (iii) change of users (e.g., increase of the population, change of users' behavior). Loubet et al. (2014) concluded that for decisions about future investments done by regional and local authorities at the scale of a river basin or a city, forecasting scenarios should be evaluated in order to inform on their potential environmental impacts. For day-to-day management of water services by operators, LCA could be used to select the most interesting solution on an environmental point of view (e.g. management of water production from different drinking water plants which withdraw water at different locations). However, there are methodological limits in LCA application at smaller temporal and spatial scales as well as uncertainties (e.g. traditional LCA models with annual averages are not suited for this goal, which require dynamic models running at hourly or daily time steps).

The level of sophistication of a LCA model should reflect the robustness required to support a particular decision-making context (Bare et al., 1999). In typical LCA studies of UWS, only average dryweather conditions are modelled while wet-weather flows originating from UWS are typically not considered, with the exception of Hadjimichael et al. (2016) who proposes to account for reduced wet-weather discharges in the LCA of different UWS upgrades in terms of nutrient inputs to the receiving waters. By nature, wet-weather flows are highly variable. For example, it is readily seen that the concentrations in wetweather flows are often relatively high in the beginning of an event in contrast to what follows, also called the first flush phenomenon which was studied for a range of catchments (Bertrand-Krajewski et al., 1998; Kim et al., 2005; Lee and Bang, 2000). Yet traditionally in LCA, pollutant discharges are aggregated over a certain time horizon and their impact characterised using steady-state mass-balance fate models. Currently it is a methodological challenge in LCA of UWS to account for discharge dynamics occurring during wet-weather flows (e.g. concentration variations at hourly or daily time steps).

Ecotoxicity impacts are particularly sensitive to time since dynamic processes drive the fate of contaminants. Traditionally in LCA, the mass of a pollutant released in the environment (i.e., the inventory result) is proportionally linked to its corresponding impact by a constant characterization factor, but timedependent processes such as mass transfer phenomena and chemical reactions are responsible for transitory states and induce the nonlinear distribution of the impact over time (Lebailly et al., 2014; Reap et al., 2008). However, it was shown that the generated impacts can be sensitive to the mode (e.g. continuous or pulsed) and timing of discharges (Owens, 1997), which have a large influence on how they are assimilated within the river system. For example, toxic pollutants (e.g. heavy metals and organic micropollutants) may have acute impacts if released in pulse discharges (resulting in shock effects subsiding 
Author-produced version of the article published in Water Research, 2017, №128, p.412-423.

The original publication is available at https://www.sciencedirect.com

Doi: 10.1016/j.watres.2017.10.039

relatively fast) or cumulative impacts with continuous discharges (resulting in long term effects)(HvitvedJacobsen et al., 2010, 1994). Concerning freshwater eutrophication there is a clear distinction between impacts of concentrated phosphorus discharges during ecologically sensitive periods (e.g. warmer temperatures and increased light for algal growth) and impacts associated with particulate phosphorus transported in stormwater during winter storm events (Withers and Jarvie, 2008).

The objective of this study was to assess potential impacts from priority compounds and nutrient pollution in UWS discharges during wet-weather events. These discharges concern the impact categories of freshwater ecotoxicity as well as freshwater eutrophication. Marine eutrophication is also considered as rivers ultimately discharge into the oceans.

The goal and scope of the present paper was to assess inventory flows (i.e. pollutant loads from the UWS) at two temporal resolutions (year (annual average) and wet-weather event) and to use these inventory flows as data inputs in a LCA with two sub-objectives: (i) to assess the significance of pollutant discharges and impacts from "intermittent" wet-weather discharges relative to average "continuous" dry-weather conditions at the year scale; and (ii) quantify pollutant discharges and impacts from additional wet-weather flows at the scale of a "wet-weather event" by including temporal variability in the life cycle inventory (LCI) for UWS.

\section{Materials and methods}

The general LCA methodology described in the ISO 14040 and 14044 standards (ISO, 2006a, 2006b) was applied in this study through the four following phases: LCA goal \& scope definition, life cycle inventory analysis (LCI), life cycle impact assessment (LCIA), and interpretation of results which are detailed hereafter. In this study, the urban catchment of the Greater Paris area (Figure 1) was chosen to develop the assessment of pollutant discharges from a European megalopolis with a combined system servicing its inner city area. The modelling of pollutant loads from this UWS was made possible thanks to recent, qualitative and quantitative data from the Paris public sanitation service (SIAAP) and OPUR. Moreover, there is a great anthropic pressure from this densely urbanized catchment (8.9 million inhabitants as of $1^{\text {st }}$ January 2014 were connected to sewer systems), which may result in significant impacts on the receiving waters (the Seine river with a median flows at Paris of about $300 \mathrm{~m}^{3} \cdot \mathrm{s}^{-1}$ ).

This catchment comprises Paris and 284 neighbouring towns spanning $1830 \mathrm{~km}^{2}$. The inner city area of Paris $\left(105 \mathrm{~km}^{2}\right)$ is characterized by a continuous dense urban fabric (i.e. approximately 20,500 inhabitants $/ \mathrm{km}^{2}$ ) with a high degree of imperviousness (> 80\%) and is dominated by residential and commercial/institutional land uses and very little industrial activity. Suburbs are areas of discontinuous dense 
Author-produced version of the article published in Water Research, 2017, N¹28, p.412-423.

The original publication is available at https://www.sciencedirect.com

Doi: 10.1016/j.watres.2017.10.039

urban fabric with a medium-high imperviousness degree $(50-80 \%)$, which are mostly residential zones with industrial activities (European Environment Agency, 2012). The Greater Paris network is mostly separate $(56 \%)$, and impervious areas serviced by separate sewers were considered as the only active areas contributing to stormwater generation. At the scale of the SIAAP network, impervious surface was estimated to be $190 \mathrm{~km}^{2}$ ( $10 \%$ of the total catchment area). A runoff coefficient value of 0.6 was chosen to calculate stormwater volumes generated from these active areas (Table 1).

Table 1. Characteristics of the Greater Paris catchment

The mean annual rainfall is of $637 \mathrm{~mm}$, for a warm temperate climate, with significant rainfall even during the driest month.

There are five wastewater treatment plants (WWTP) which released 922 million $\mathrm{m}^{3}$ of treated wastewater in 2013, of which 533 million $\mathrm{m}^{3}$ were produced during dry weather, and 389 million $\mathrm{m}^{3}$ during wet-weather. This treatment capacity amounts to an average of 2.53 million $\mathrm{m}^{3} /$ day (Tabuchi and Penouel, 2014).

Figure 1. Study area: SIAAP urban catchment and the main sewer network servicing the Greater Paris. Wastewater treatment plants discharging into the Seine and the Marne rivers are included (blue dots). Source: SIAAP.

\subsection{LCA goal and scope definition}

The main goal of this study is to compare relative contributions of pollutants discharged in dry-weather flows and wet-weather flows. Using the LCA framework, this study compares inventories of discharged pollutants as well as their associated impacts to receiving waters. The scope of the study covers discharges generated by an urban catchment with combined and separate sewer systems at two temporal scales, (i) during one year, and (ii) during wet-weather events. The potential impacts will be assessed for three categories relevant to waterborne pollutants, e.g. eutrophication (marine and freshwater) and freshwater ecotoxicity.

Recent research carried out in the framework of the OPUR programme has provided the first comprehensive, broad overview of priority pollutant contamination of stormwater and CSOs. Since CSOs are an untreated mixture of raw wastewater and stormwater, the wastewater quality was also investigated.

The conceptual diagram in Figure 2 presents the system boundaries and inventoried flows towards the ecosphere (receiving waters) generated in the urban technosphere (man-made processes and systems) with both types of sewer networks. All flows were assessed in terms of volume and pollutant concentrations, but only flows from the technosphere are converted into potential impacts (LCIA).

In Paris, the high-density inner area is drained by a mostly combined sewer system, collecting wastewater and stormwater for treatment in a wastewater treatment plant, sometimes leading to CSO discharges during 
Author-produced version of the article published in Water Research, 2017, N¹28, p.412-423.

The original publication is available at https://www.sciencedirect.com

Doi: 10.1016/j.watres.2017.10.039

storm events with a total annual volume of 13.7 million $\mathrm{m}^{3}$ in 2013 (Tabuchi and Penouel, 2014). The surrounding urban developments are serviced by a separate sewer system at the end of which polluted stormwater is discharged into local watercourses (See Figure A1 in Annex A of Supporting Information). The UWS includes several large storage capacities for combined flows (of wastewater and stormwater) during storm events, as well as an automated management system for these flows which enabled a significant reduction in CSO discharges in this urban catchment. Thus, other cities may have a higher proportion of CSO discharges relative to the total volume in their sewage system.

Figure 2. Conceptual diagram of the modelled urban catchment with flows reaching the receiving waters

\subsection{Life Cycle Inventory analysis: available data regarding flows reaching receiving waters}

This section describes the available data to conduct the Life Cycle Inventory (LCI) analysis on the Paris case study.

\subsubsection{Classification of wet-weather events}

Since the goal and scope of the study is to determine, at the year and event scales, the significance of wet-weather pollutant discharges to receiving waters, three categories of wet-weather events are proposed. The first event category is representative of a dry weather day (T1) where the only flows reaching the river are treated effluents. Wet-weather events (where a minimum of $1 \mathrm{~mm}$ of rainfall has been recorded) were grouped into the two other categories: (i) T2, wet-weather with untreated stormwater reaching the river from the separate sewer systems (mild storms); and (ii) T3, wet-weather with untreated stormwater and CSO discharges reaching the river (severe storms). Table 2 summarises the characteristics of the three types of events.

\section{Table 2. Proposed classification for wet-weather events for the Paris case study}

The year 2013 was chosen as reference year for flows since it was a year with an average number of wetweather events compared to the historic time series of the Paris area. It had 231 days of dry-weather, 75 days with wet-weather events of type T2, and 59 days of type T3 were recorded, which amounts to a total of $707 \mathrm{~mm}$ of significant rainfall (i.e. rainfall depth greater than $1 \mathrm{~mm}$ ) in 2013. Volumes of treated effluents and CSO discharges were measured over 24-hour periods for 2013. Surface runoff volumes were derived using the total area of active impervious sub-catchments serviced by a separate-only sewer system $\left(190 \mathrm{~km}^{2}\right)$ and the adjusted recorded daily rainfall depth with a runoff coefficient of 0.6 , which corresponds to a high density urban area. More precise stormwater volumes would be obtained with a calibrated rainfall-runoff model, using spatial differentiation and varying runoff coefficients depending on the land uses. 
Author-produced version of the article published in Water Research, 2017, N¹28, p.412-423.

The original publication is available at https://www.sciencedirect.com

Doi: 10.1016/j.watres.2017.10.039

At an annual scale, untreated stormwater volume was hence estimated at 80.7 million $\mathrm{m}^{3}$ (Tabuchi and Penouel, 2014).While this approach, also known as the rational method, does not acknowledge variations in stormwater volumes by using a single value for runoff coefficient for each contributing sub-catchment with impervious surfaces and separate sewers, this choice was motivated by the goal of assessing in a first order analysis, the scale of stormwater pollutant discharges in terms of inventory and impacts. Indeed, with no existing LCA studies of urban wastewater systems (UWS) during wet-weather, this study is a first step towards the inclusion of wet-weather discharges in the LCA models of UWS.

For each of the flows described in Figure 2, quality parameters include common pollutants routinely measured in wastewater, and a broad range of priority pollutants.

\subsubsection{Routine water quality parameters (common pollutants)}

Quality parameters measured in the inventoried flows from all WWTPs managed by SIAAP include routine wastewater quality parameters, such as ammonium, phosphates and total oxidized nitrogen (nitrates and nitrites). Data for the characterization of flows from Greater Paris include daily loads for treated effluents from the wastewater treatment plants (summarised in 2014 SIAAP's annual activity report), concentrations in stormwater from dense urban and sub-urban (separate sewer) catchments for 20 storms between 2008 and 2009 (Zgheib et al., 2012) and 52 measurements of CSO discharges from Greater Paris by Gasperi et al. (2012) in the CSO database. For stormwater, concentrations on classical parameters (ammonium, phosphates and total phosphorus) were measured, however for oxidized nitrogen forms (nitrates and nitrites), concentration mean and standard deviation in stormwater were taken from another study (Taylor et al., 2005). Data for CSO discharges was retrieved from the CSO database with 52 measurements, however there were no measured concentrations on nitrates and nitrites, which are negligible in these flows.

\subsubsection{Monitored priority pollutants}

The OPUR research programme provided new insights into the stormwater quality from various urban watersheds, including the Greater Paris area (Zgheib et al., 2012, 2011). In order to include specific urban pollutants, the WFD list of priority pollutants has been extended from 33 substances to a total of 88 ( 80 organic substances and eight metals) chosen for their representativeness in stormwater (Zgheib, 2009; Zgheib et al., 2008). The same methodology was applied to monitor CSO discharges from the largest CSO outfall in the Paris metropolitan area as well as raw wastewater (Gasperi et al. 2012). Of the 88 priority pollutants monitored in wet-weather flows (stormwater and CSOs), 58 were consistently found and 30 were 
Author-produced version of the article published in Water Research, 2017, N¹28, p.412-423.

The original publication is available at https://www.sciencedirect.com

Doi: 10.1016/j.watres.2017.10.039

never detected (Figure 3). Total event mean concentrations and the detection frequency are given as well as details in the measurement procedure of Gasperi et al. $(2012,2014)$ and Zgheib et al. $(2009,2012)$.

Figure 3. List of 88 substances frequently found in stormwater, complementing the WFD list of priority pollutants (Zgheib et al., 2008). Among these substances, there are EU WFD priority dangerous substances (purple), substances never detected in monitored flows from SIAAP (orange) and substances included in the assessment for which there are available characterization factors in USEtox (yellow).

Concentrations (average and standard deviation values) of priority pollutants in treated (secondary) effluents discharged from wastewater treatment plants in the Paris UWS have been monitored in a recent study of the removal efficacy of a tertiary treatment step (Mailler et al., 2015) at the Seine Centre WWTP (Paris Agglomeration). Where data concerning relevant pollutants was missing from this study, concentration and occurrence data in raw wastewater given by Gasperi et al. (2012) was used for some priority pollutants, along with removal efficacies in a conventional activated sludge treatment step (Ruel et al., 2012, 2010). Priority pollutant concentration data in stormwater was retrieved from the campaign on 20 storms by Zgheib et al. (2012), while for CSO discharges only four rain events in 2010 were monitored (Gasperi et al., 2012). Pollutant discharges which occurred upstream of the UWS in this study (upstream catchment loading) and measured at Choisy-le-Roi, were included in the inventory for information purpose despite the scarcity of data on the range of priority pollutants. However, these upstream discharges were not converted into impacts as they are not UWS discharges per se. A summary of the data used is available in the Supporting Information (See Table A1 in Annex A of Supporting information).

In this study it was assumed that the treatment efficacy in the WWTP remains unchanged even during wetweather periods with CSO discharges where it is evident that the WWTP is overloaded. This assumption can hold for the SIAAP wastewater treatment plants since it has been shown that the treatment efficacy of the Seine-Centre WWTP was still good during wet-weather periods (Gilbert et al., 2012). This is a simplification made for this study as the focus is not on the WWTP treatment performance but rather on the unmanaged flows reaching the receiving waters.

\subsubsection{Statistical treatment of LCl data}

Pollution in runoff from urban areas and roads is complex compared to the pollution originating from e.g. a specific treatment plant. Its chemical characteristics are dependent on the nature of urban surfaces which are washed off, as well as natural processes (e.g. wet and dry deposition) and anthropogenic activities in the catchment. Rainfall is a stochastic phenomenon hence it becomes relevant to describe this pollution in terms of a probability, a frequency of occurrence or a return period (Hvitved-Jacobsen et al., 2010). 
Author-produced version of the article published in Water Research, 2017, N¹28, p.412-423.

The original publication is available at https://www.sciencedirect.com

Doi: 10.1016/j.watres.2017.10.039

As a preliminary analysis, the concentrations of common pollutants in wastewater (ammonium, phosphates and total oxidized nitrogen) were tested for lognormality using a Chi-square goodness-of-fit test. These parameters indeed followed a lognormal distribution in wastewater which was also demonstrated for organic matter and total suspended solids in stormwater across several sites in France (Gasperi et al., 2014). The number of priority pollutants measurements was not sufficient to conduct proper lognormality tests. Their concentrations were therefore assumed to follow lognormal distributions similar to the common pollutants. In order to assess the variability in inventory flows at the scale of a year and during wet-weather events, it is required to determine the mass load of pollutant $i$ (mean and standard deviation, in $\mathrm{kg}$ ) in a given flow emitted into the environment from a single storm or a series of storm events (year scale). Using the pollutant concentration value and volume of flow emitted, the mass load of pollutant $i$ is computed as follows:

$$
\left(\overline{m_{l}}, \sigma_{m_{i}}\right)=\left(\overline{c_{l}}, \sigma_{C_{i}}\right) * V
$$

With:

$\left(\overline{c_{l}}, \sigma_{C_{i}}\right)$, mean and standard deviation in the concentration in pollutant $i(\mathrm{mg} / \mathrm{L}$ or $\mu \mathrm{g} / \mathrm{L}) ;\left(\overline{m_{l}}, \sigma_{m_{i}}\right)$, mean and standard deviation mass of pollutant $i$ emitted $(\mathrm{kg})$, and $\mathrm{V}$ the volume of flow reaching the river $\left(\mathrm{m}^{3}\right)$ which can be a yearly volume or an event volume.

However, given the various sources and sampling strategies of urban flows, the obtained data on pollutant concentrations is heterogeneous in quality and the statistical treatment resulting in inventory flows (mean and standard deviation) is detailed in Figure 4.

Figure 4. Statistical treatment of data to compute inventory flows for the pollutants found in treated wastewater effluents (WTP), stormwater (SWR) and combined sewer overflow (CSO) discharges.

On one hand, for some flows, time series or daily measurements (e.g. for common pollutants in treated WWTP effluents) are available for which the concentration mean and standard deviation are straightforward to compute. While on the other hand, statistically-processed concentration data are available in a variety of forms such as (minimum, maximum, median values) or decile ranks (e.g. d10, d50, d90). In this case, under the hypothesis of lognormality, the heterogeneous concentration data is fitted to a lognormal probability distribution using the Matlab® original "fitdist" function, which then yields a concentration mean and standard deviation. Concerning priority pollutants which are measured with variable frequencies in samples (because they are often found at low concentrations, sometimes below the current limits of quantification in the order of the $\mathrm{ng} / \mathrm{L}$ ), we chose to account within each flow for frequencies of occurrence (in \%) for each priority pollutant. Mean pollutant concentrations were adjusted with the associated frequencies of occurrence (resulting in weighted average concentrations) within each flow. Indeed, a pollutant which was measured 
Author-produced version of the article published in Water Research, 2017, N¹28, p.412-423.

The original publication is available at https://www.sciencedirect.com

Doi: 10.1016/j.watres.2017.10.039

with a frequency of $25 \%$ (i.e. in one out of four samples) should be less represented than a pollutant systematically measured in a given flow.

In order to characterize the specific volume distribution in wet-weather flows at the scale of a wet-weather event (T2 and T3), these flow volumes were estimated with three statistical values: $1^{\text {st }}, 5^{\text {th }}$ (median) and $9^{\text {th }}$ deciles. The volumes used for the inventoried flows at year and event scales are summarized in Supporting information (See Table A2 in Annex A of Supporting information). Finally, for each flow pollutant mass loads at the year scale were estimated using concentration values and total volume. At the event scale, daily event volumes were used instead of the total volume to compute event pollutant mass loads.

\subsection{Life cycle impact assessment}

\subsubsection{LCIA method selection}

This specific application of LCA concerns only discharges to water and does not comprise the entire life cycle of the studied urban water system including infrastructure and operation. In this context, impact categories such as resource depletion or climate change are not relevant and only a small set of indicators related to water pollution must be selected from the available methods.

A requirement of the ISO14044 standard (ISO, 2006b) is that the characterisation factors be based on environmental mechanisms that link human interventions to a set of areas of protection. For freshwater eutrophication, the generally accepted assumption in LCIA is that only phosphorus compounds are contributing to this impact, as the majority of freshwater ecosystems are limited by phosphorus availability. However, coastal marine waters are assumed to be nitrogen-limited; hence nitrogen compounds reaching the ocean potentially cause marine eutrophication.

The ReCiPe Midpoint v1.09 (H) method (Goedkoop et al., 2009) was chosen for the impact assessment of wastewater pollutants causing freshwater eutrophication and marine eutrophication as it is based on the latest recommendations by the European Commission (JRC European commission, 2011). Freshwater eutrophication and marine eutrophication potentials for phosphates, total oxidized nitrogen and ammonium are expressed respectively as $\mathrm{kgP}$ and $\mathrm{kgN}$.

Regarding the impact assessment of priority pollutants on freshwater ecotoxicity, USEtox was used (Henderson et al., 2011; Rosenbaum et al., 2008). In the latest version USEtox v2.01, an updated ecotoxicological characterization model for metals was included (Diamond et al., 2010; Dong et al., 2014; Gandhi et al., 2010). The freshwater ecotoxicity potential is expressed in potentially affected fraction of species (PAF) at midpoint level due to change in substance concentration in freshwater, integrated over the 
Author-produced version of the article published in Water Research, 2017, N¹28, p.412-423.

The original publication is available at https://www.sciencedirect.com

Doi: 10.1016/j.watres.2017.10.039

freshwater volume $\left(\mathrm{m}^{3}\right)$ per substance mass emitted to freshwater $(\mathrm{kg}), \mathrm{PAF} \cdot \mathrm{m}^{3} / \mathrm{kg}$. Of the 58 priority pollutants monitored in all urban flows, 43 had ecotoxicity characterization factors and were included in the study.

\section{Results}

Details on inventory results (i.e. mass loads of pollutants entering the receiving waters) and impact assessment scores on the aquatic categories for the monitored flows are available in Supporting Information, Annex B. The section below presents the general results of the calculated mass loads and impact contributions for the three classes of archetypal weather days for the Greater Paris area: dry weather (T1), wet-weather without discharges of untreated sewage from CSOs (T2), and wet-weather with discharges of raw untreated sewage from CSOs (T3).

\subsection{Pollutant loads (LCl)}

\subsubsection{Year scale}

In 2013, WWTPs discharged a much greater volume aggregated over dry- and wet-weather days (922 million $\mathrm{m}^{3}$ ) than the runoff due to wet-weather events (respectively 27 million $\mathrm{m}^{3}$ and 53.7 million $\mathrm{m}^{3}$ across resp. all T2 events and T3 events) and CSO discharges (13.7 million $\mathrm{m}^{3}$ ) (See Table A2 in Annex A of Supporting Information).

Some common pollutants showed a great range of variation across the monitored flows. The load of total oxidized nitrogen was found to be three orders of magnitude larger in treated effluents compared to wetweather loads (See Figure B1 in Annex B of Supporting Information). Generally, the loads from treated effluents were higher than the wet-weather loads (aggregated wet-weather flows in 2013). Data on yearly loads of common pollutants from the upstream catchment was available only for ammonium and total phosphorus.

Most wet-weather loads of priority pollutants were in the same order of magnitude as those in treated effluents (See Figure B2 in Annex B of Supporting Information). Regarding metals, the inventory results are expressed as total metal loads, using the free ion fraction calculated in the LCIA method, USEtox.

All metal species were found in comparable loads across all flows, with copper and zinc also present in the upstream catchment loads. The loads of four polycyclic aromatic hydrocarbons (PAH) (anthracene, fluoranthene, pyrene, and dibenzo[a,h]anthracene) were an order of magnitude higher in stormwater than in treated effluents and CSO discharges. Of these PAHs, the first three and benzo[a]pyrene showed important 
Author-produced version of the article published in Water Research, 2017, №128, p.412-423.

The original publication is available at https://www.sciencedirect.com

Doi: 10.1016/j.watres.2017.10.039

loads from the upstream catchment. Pesticides did not show a clear tendency with some showing higher loads in treated effluents (isoproturon) while some were dominant in stormwater (glyphosate). Two alkylphenols (4-nonylphenol and butylphenol) were found in similar amounts and almost always detected (measurement occurrences greater than 90\%) in treated effluents and stormwater.

From a quantitative point of view, the total metal forms of copper and zinc were the two compounds with the greatest annual discharged loads, in the range of $10^{3}$ to $10^{4} \mathrm{~kg}$ per year. They are followed by lead, DEHP, chromium, and glyphosate in the range of $10^{2}$ to $10^{3} \mathrm{~kg}$ per year.

\subsubsection{Wet-weather event scale}

Event scale loads are shown in the following section for median volume values $\left(5^{\text {th }}\right.$ decile, d50) of wetweather flows. At the wet-weather event scale common pollutants followed the same trends as the year scale, without any marked differences in loads of common pollutants between dry-weather treated effluents and wet-weather flows. Hence the pollution generated during wet-weather events was quantitatively similar to the pollution of the treated effluents (See Figure B1 in Annex B of Supporting Information ).

At the event scale priority compounds also showed similar trends as the year scale, only a bit more marked. Copper and zinc were found in comparable amounts in weather treated effluents and wet-weather flows. However lead showed a load one order of magnitude greater in stormwater and CSO discharges than in treated effluents. PAHs that were predominant in stormwater at the year scale are even more so at the event scale with a difference in substance loads of up to two orders of magnitude.

From a quantitative point of view, discharges of all metal elements, nonylphenol, DEHP and glyphosate were in the range of 1 to $10 \mathrm{~kg} / \mathrm{d}$ when most other priority compounds loads ranged between $10^{-4}$ to $10^{-1} \mathrm{~kg} / \mathrm{d}(\mathrm{See}$ Figure B4 in Annex B of Supporting Information ).

\subsection{Impact assessment}

Routine water quality parameters are the only substances counting towards the aquatic categories of eutrophication (marine and freshwater) while all priority compounds inventoried in this study are counting towards the freshwater ecotoxicity category.

At the year scale, contribution analysis for freshwater ecotoxicity showed that wet-weather flows (stormwater from T2 and T3 events, and CSO discharges from T3 events) moderately contributed to the total impact on freshwater ecotoxicity (34\%), with treated effluents accounting for the remaining 66\% (Figure 5). Of the wetweather flows, CSO discharges were the least contributing, followed by untreated stormwater. Results for the 
Author-produced version of the article published in Water Research, 2017, №128, p.412-423.

The original publication is available at https://www.sciencedirect.com

Doi: 10.1016/j.watres.2017.10.039

eutrophication categories (marine and freshwater) showed a similar trend albeit less marked, and are presented in Supporting information (See Figures B5 to B10 in Annex B of Supporting Information).

Figure 5. Contributions to the Freshwater ecotoxicity impacts (PAF.m3.d) of urban dry-and wet-weather flows at year scale

At the event scale, wet-weather flows had even greater contributions on freshwater ecotoxicity with up to $62 \%$ of the total impact in a T3 wet-weather event (Figure 6).

Figure 6. Contributions to the Freshwater ecotoxicity impacts (PAF.m3.d) of urban dry- and wet-weather flows at event scale (d50, median wet-weather volumes)

A detailed contribution analysis showed the notable contributors on the freshwater ecotoxicity impact at the year scale (Table 3). The ranking was not modified when considering the event scale as the contributions of the three most important pollutants did not change, therefore masking variations from the minor contributors (under 5\%).

Table 3. Top 6 contributors to freshwater ecotoxicity

Table 3 underlines that two metal elements $(\mathrm{Cu}(\mathrm{II})$ and $\mathrm{Zn}(\mathrm{II}))$ clearly dominated this impact, as they alone made up for over $99 \%$ of the ecotoxicity score, in all considered flows. Then in $3^{\text {rd }}$ position there was $4-$ nonylphenol in treated effluents and pyrene in wet-weather flows.

Detailed contribution analysis of the marine eutrophication results demonstrated that this impact was mostly driven by total oxidized nitrogen $\left(\mathrm{NO}_{2}^{-}\right.$and $\left.\mathrm{NO}_{3}^{2-}\right)$ in treated effluents and by ammonium $\left(\mathrm{NH}_{4}^{+}\right)$in both wetweather flows at the year scale (See Table B1 in Annex B of Supporting Information). Freshwater eutrophication was mostly driven by total phosphorus in all flows.

\section{Discussion}

\subsection{Discharges from the UWS}

Despite a reduced total annual volume for both wet-weather flows (i.e. stormwater and CSO discharges, arising to 94.4 million $\mathrm{m}^{3}$ ) in comparison with WWTP effluents $\left(922\right.$ million $\left.\mathrm{m}^{3}\right)$, the computed loads at a year scale for most priority compounds in these flows were within the same order of magnitude as in treated WWTP effluents. This is due to relatively high measurements in wet-weather flows. The predominance of some PAHs in stormwater is expected as these compounds originate from road traffic.

\section{- Representativeness of available data used to calculate mass loads}

Data representativeness in stormwater pollutants could be increased by accounting for the significant site variability by using pollutant concentrations from other catchments. Concerning available data on priority 
Author-produced version of the article published in Water Research, 2017, N¹28, p.412-423.

The original publication is available at https://www.sciencedirect.com

Doi: 10.1016/j.watres.2017.10.039

compounds which is summarized in Table A1 (Supporting Information, Annex A), the heterogeneity in representativeness of measurements to determine concentration values across all flows is notable, with CSO discharges $(n=4)$ (Gasperi et al., 2012), treated wastewater effluents ( $n=11$ or 14) (Gasperi et al., 2012; Mailler et al., 2015), and stormwater ( $n=17$ ) (Gasperi et al., 2012; Zgheib et al., 2012). Also, priority compounds were generally detected across all flows during the measurement campaigns but some were detected at a frequency of $30 \%$ or lower, especially in stormwater and CSO discharges (e.g. volatile organic compounds such as benzene, ethylbenzene, toluene, xylenes, tetrachloroethylene). Accounting for the frequency of detection in the load calculation has given a better representation of the contamination by these compounds. However, uncertainties around the concentration values used may be of the same order of magnitude as the mean concentration values; this is why care should be taken in the interpretation of associated impacts on ecotoxicity. Concerning volumes derived from daily recorded rainfall depths, the associated uncertainties were low compared to uncertainties associated with concentration measurements primarily due to the sampling procedure (few samples for wet-weather flows). Results using most conservative volume values $\left(9^{\text {th }}\right.$ decile, $\left.\mathrm{d} 90\right)$ of wet-weather flows are given in the Supporting information file (See Figures B7, B10, B11 in Annex B of Supporting Information ), and the general conclusions remain the same.

\section{- Consideration of point-source and non-point source pollutants}

This study included point source pollutants (e.g. alkylphenols and PCBs in treated wastewater) and nonpoint source pollutants (e.g. PAH and pesticides from untreated stormwater). LCA studies of UWS traditionally focused on continuous point-source pollutants (discharges from WTP), omitting non-point source pollutants linked with untreated stormwater from episodic storm events. Indeed, current LCIA methods are steady-state models and do not account for discharge dynamics. Concerning freshwater ecotoxicity, the USEtox LCIA model assesses toxicological effects of over 3000 chemicals emitted into the environment, and the outputs of this model are characterization factors for these chemicals. They represent the cause-effect chain of freshwater ecotoxicity and are modelled by a fate component, as well as an exposure and toxicity components (Henderson et al., 2011). Then, characterization factors are used to make quantitative rankings for chemicals. However, this model does not differentiate between point-source, chronic discharges and nonpoint source, episodic discharges. In order to cope with this issue, we propose an $\mathrm{LCl}$ of non-point source pollutant discharges for several weather categories calculated at the scale of a day. Then, the impacts of these pollutant discharges are calculated by using USEtox characterization factors. 
Author-produced version of the article published in Water Research, 2017, N¹28, p.412-423.

The original publication is available at https://www.sciencedirect.com

Doi: 10.1016/j.watres.2017.10.039

\subsection{Upstream catchment loadings}

It is interesting to discuss the significance of the mass loadings from the UWS relative to upstream catchment loadings in the river Seine, which are flows originating upstream of the SIAAP urban catchment and measured at Choisy-le-Roi. As shown in Figure B2 in Annex B of Supporting Information, mass loadings for six priority pollutants which were monitored in the upstream river section indicate that there may be a significant "legacy" of pollutants from sources upstream of the UWS which include highways and roads. Indeed, the link between vehicular combustion products and runoff quality has been confirmed in various studies that show that highway discharges have a specific chemical fingerprint including PAHs and metal species (D'Arcy et al., 2000; Ellis et al., 1997; Ellis and Mitchell, 2006). However, the scarcity of the monitoring data on priority pollutants in upstream river sections (only seven compounds) is notable, given that the scope of the regulatory analysis of upstream flows is rather limited. The research on urban flow contamination by priority pollutants could certainly benefit from a broader range of priority pollutant concentrations to help assess the relative importance of the mass loadings from the SIAAP urban catchment.

\subsection{Life cycle impact assessment results}

\section{- Comprehensiveness of ecotoxicity assessment}

Application of the latest LCIA method USEtox to the mass loadings defined in the inventory step yields results for the priority compounds included in this study. These first results are in agreement with other studies on different catchments where heavy metals (especially copper and zinc), PAHs, DEHP and pesticides were found to be the main pollutants of general concern in stormwater runoff (Birch et al., 2011). However, it is important to bear in mind that they show only a fraction of the total impact on ecotoxicity, given that there are many substances that are missing from the inventory because of a lack of characterization factors to date. Also, in literature, the presence of other pollutants such as perfluoroalkyl compounds, polybrominated diphenyl ethers, and bisphenol A in urban flows is confirmed (Gasperi et al., 2014). Hence including more priority compounds requires new characterization factors, and some compounds that should be added are listed in Figure 3.

\section{- Impacts from metal species on freshwater ecotoxicity}

Two metal species $(\mathrm{Cu}(\mathrm{II})$ and $\mathrm{Zn}(\mathrm{II}))$ are consistently ranked as top contributors in freshwater ecotoxicity across all flows. These metals are therefore of high priority. Besides significant amounts of metals 
Author-produced version of the article published in Water Research, 2017, N¹28, p.412-423.

The original publication is available at https://www.sciencedirect.com

Doi: 10.1016/j.watres.2017.10.039

discharged (described in the inventory section 3.1), the characterization factors of these metals are also high with $\mathrm{Pb}(\mathrm{II})$ having the greatest ecotoxicity potential in freshwater followed by $\mathrm{Cu}(\mathrm{II})$ and $\mathrm{Zn}$ (II) (Gandhi et al., 2011).

Characterization factors and the parameter values for the most contributing priority compounds identified in Section 3.2 are given in Table B2 in Annex B of Supporting Information. $\mathrm{Cu}(\mathrm{II})$ has the highest factor followed by dieldrin and pyrene, and $\mathrm{Zn}(\mathrm{II})$. It should be noted that as a step ahead of its predecessor USEtox 1.0, recent developments implemented in USEtox 2.01 have addressed metal-specific issues such as speciation, bioavailability and freshwater chemistry (Diamond et al., 2010; Dong et al., 2014; Gandhi et al., 2010), as well as updated ecotoxicological effect data as described in Fantke et al. (2015).

\section{Conclusions}

This paper proposes an approach to account for intermittent wet-weather discharges from an urban wastewater system in LCA and assess their relative importance regarding water quality impacts (eutrophication and ecotoxicity). This method was applied to the Greater Paris catchment, whose urban wastewater system is representative of a European megalopolis. Major results for this case study are highlighted in the following, as well as recommendations and challenges on the way to conduct such a LCA:

- Data quality was very heterogeneous, which required a probabilistic approach to get a consistent life cycle inventory for all flows. For example, data on classical parameters in wet-weather flows was scarce. While priority pollutants were the recent focus of research in dry-and wet-weather discharges, there are still research efforts to be made to better characterize CSO discharges (only four events monitored for the case study).

- The proposed choice of wet-weather event classification into categories allowed to better define wetweather discharges and underlined the importance of their associated pollution relative to dryweather discharges from an urban wastewater system at the scale of a day. This study demonstrated that for the (climatic and infrastructure-related) characteristics of the UWS servicing the Greater Paris, the potential impacts from episodic wet-weather discharges were significant also at a year scale, despite the stormwater management.

- Compared to untreated stormwater, CSO discharges were potentially less contributing to (ecotoxicity and eutrophication) impacts. It may be explained by the low vulnerability of the Greater Paris UWS which features an important storage capacity during wet-weather events, coupled to the dynamic 
Author-produced version of the article published in Water Research, 2017, N¹28, p.412-423.

The original publication is available at https://www.sciencedirect.com

Doi: 10.1016/j.watres.2017.10.039

management of flows (routing inside the sewer system), which allow for few combined sewer overflows.

- In the case of the Greater Paris catchment, it was demonstrated that at the event scale, stormwater flows are the greatest contributors to the freshwater ecotoxicity impact because of two metal elements (copper and zinc) found in those flows, even with a conservative runoff coefficient value. Impacts on freshwater ecotoxicity may therefore be greater with higher runoff coefficients (e.g. 0.8 or $0.9)$.

- Stormwater management upstream of the catchment would be interesting to reduce stormwater volume using a blue-green infrastructure to promote local infiltration (e.g. with raingardens or bioretention systems) and where necessary, to treat locally more polluted stormwater from urban surfaces with greater release rates (Bressy et al., 2012).

- Given the significance of the wet-weather discharges, further research into how to include temporally-differentiated discharges in the LCIA framework for eutrophication and ecotoxicity is needed to better understand how the performance of an UWS system affects the receiving environment at different local weather conditions.

- The LCA approach is well-suited to a comparative assessment of wet-weather infrastructures in urban water systems, using physically-based drainage systems models coupled with an inventory $(\mathrm{LCl})$ of wet-weather discharges to assess the changes in impacts at the event scale for different event categories. However, the inclusion of acute toxicity impacts following a peak discharge at the beginning of a storm (e.g. first flush phenomenon) remain a methodological challenge.

Acknowledgement - The authors are members of the ELSA research group (Environmental Life Cycle and Sustainability Assessment, http://www.elsa-lca.org/) and thank all ELSA members for their advice. This work was supported by the French National Research Agency (ANR), the Occitanie Region, ONEMA and the industrial partners (BRL, SCP, SUEZ, VINADEIS, and Compagnie Fruitière) of the Industrial Chair for Environmental and Social Sustainability Assessment 'ELSA-PACT' (ANR grant no. 13-CHIN-0005-01). The authors are grateful to the OPUR and INOGEV partners and the Interdepartmental Association for Sewage Disposal in Paris Conurbation (SIAAP) for providing data for this study. 
Author-produced version of the article published in Water Research, 2017, №128, p.412-423.

The original publication is available at https://www.sciencedirect.com

Doi: 10.1016/j.watres.2017.10.039

\section{Tables}

Table 1. Characteristics of the Greater Paris catchment

\begin{tabular}{|lcccc|}
\hline \multicolumn{1}{|c}{ Sewer system } & $\begin{array}{c}\text { Drainage area } \\
\left(\mathrm{km}^{2}\right)\end{array}$ & $\begin{array}{c}\text { Share of total } \\
\text { area (\%) }\end{array}$ & $\begin{array}{c}\text { Corresponding } \\
\text { impervious area }\left(\mathrm{km}^{2}\right)\end{array}$ & $\begin{array}{c}\text { Runoff coefficient } \\
\text { value chosen for } \\
\text { active area (1) }\end{array}$ \\
Separate & 1032 & $56 \%$ & 190 & 0.6 \\
Combined & 550 & $30 \%$ & 235 & n.a.(2) \\
Hybrid & 249 & $14 \%$ & 85 & n.a.(2) \\
\hline \multicolumn{1}{|c|}{ Total area $\left(\mathrm{km}^{2}\right)$} & 1830 & & 509 & \\
\hline
\end{tabular}

(1) Effective impervious area which generates stormwater and is directly connected to stream channels

(2) Non relevant since storm water is (partially) collected with domestic wastewater. It may contribute to CSO discharges which are assessed separately in this study.

Table 2. Proposed classification for wet-weather events for the Paris case study

\begin{tabular}{|c|c|c|c|c|c|}
\hline \multirow[b]{2}{*}{ Event type } & \multirow[b]{2}{*}{ Category } & \multirow[b]{2}{*}{$\begin{array}{l}\text { Rainfall event } \\
\text { specificity }\end{array}$} & \multicolumn{3}{|c|}{ Flows reaching surface water } \\
\hline & & & $\begin{array}{l}\text { Treated effluents } \\
\text { (WTP) }\end{array}$ & $\begin{array}{l}\text { Untreated } \\
\text { stormwater } \\
\text { (SWR) }\end{array}$ & $\begin{array}{l}\text { CSO discharges } \\
\text { (CSO) }\end{array}$ \\
\hline T1 & Dry weather & $<1 \mathrm{~mm} /$ event & $x$ & & \\
\hline $\mathrm{T} 2$ & $\begin{array}{l}\text { Wet-weather } \\
\text { mild storm }\end{array}$ & $\begin{array}{l}\geq 1 \mathrm{~mm} / \text { event, no } \\
\text { overflows }\end{array}$ & $x$ & $x$ & \\
\hline T3 & $\begin{array}{l}\text { Wet-weather } \\
\text { severe storm }\end{array}$ & $\begin{array}{l}\geq 1 \mathrm{~mm} / \text { event, } \\
\text { overflows }\end{array}$ & $x$ & $x$ & $x$ \\
\hline
\end{tabular}

Table 3. Top 6 contributors to Freshwater Ecotoxicity

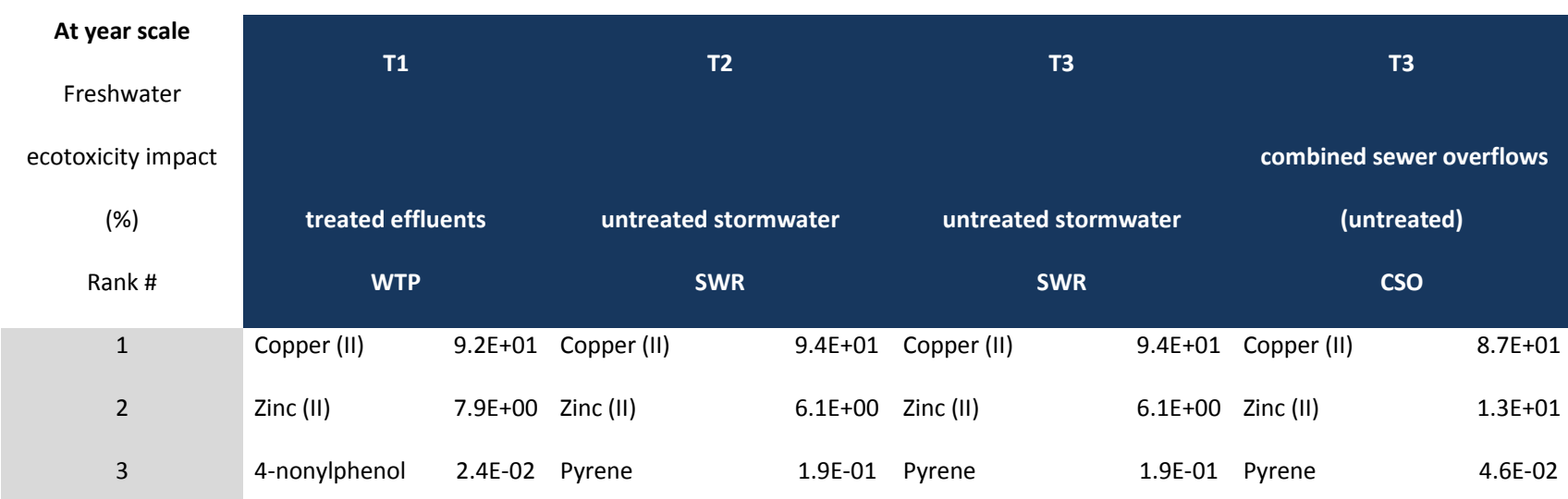


Author-produced version of the article published in Water Research, 2017, N¹28, p.412-423.

The original publication is available at https://www.sciencedirect.com

Doi: 10.1016/j.watres.2017.10.039

$\begin{array}{clllllllll}4 & \text { Chromium (III) } & 5.5 \mathrm{E}-03 & \text { Benzo[a]anthracene } & 2.7 \mathrm{E}-02 & \text { Benzo[a]anthracene } & 2.7 \mathrm{E}-02 & \text { Dieldrin } & 3.1 \mathrm{E}-02 \\ 5 & \text { Pyrene } & 2.7 \mathrm{E}-03 & 4-\text {-nonylphenol } & 2.4 \mathrm{E}-02 & \text { 4-nonylphenol } & 2.4 \mathrm{E}-02 & \text { Benzo[a]anthracene } & 1.8 \mathrm{E}-02 \\ 6 & \text { Isoproturon } & 9.1 \mathrm{E}-04 & \text { Fluoranthene } & 9.4 \mathrm{E}-03 & \text { Fluoranthene } & 9.4 \mathrm{E}-03 & \text { Lead (II) } & 6.2 \mathrm{E}-03\end{array}$

\section{References}

Angerville, R., 2009. Ecotoxicological Risk Assessment Related to the Discharge of Urban Wet Weather Effluent (UWWE) in the Streams: Case Study for a French City and an Haitian City. INSA Lyon \& Ecole Nationale des Ponts et Chaussées.

Bare, J.C., Pennington, D.W., Udo de Haes, H.A., 1999. Life cycle impact assessment sophistication. Int J Life Cycle Assess 4, 299-306.

Becouze-lareure, C., Bazin, C., Namour, P., Breil, P., Perrodin, Y., 2012. Multi-Level Approach of the Ecotoxicological Impact of a Combined Sewer Overflow on a Peri-Urban Stream. J. Water Resour. Prot. 4, 984-992.

Bertrand-Krajewski, J.-L., Chebbo, G., Saget., A., 1998. Distribution of pollutant mass vs volume in stormwater discharges and the first flush phenomenon. Water Res. 32, 2341. doi:10.1016/S00431354(97)00420-X

Birch, H., Mikkelsen, P., Jensen, J., Lützhøft, H., 2011. Micropollutants in stormwater run-off and combined sewer overflow in the Copenhagen area, Denmark. Water Sci. Technol. 64, 485-493.

Bressy, A., Gromaire, M.C., Lorgeoux, C., Saad, M., Leroy, F., Chebbo, G., 2012. Towards the determination of an optimal scale for stormwater quality management: Micropollutants in a small residential catchment. Water Res. 46, 6799-6810. doi:10.1016/j.watres.2011.12.017

D’Arcy, J.B., Ellis, J.B., Ferrier, R.C., Jenkins, A., Dils, R., 2000. Diffuse Pollution Impacts: The Environmental and Economic Effects of Diffuse Pollution in the UK. Dalton, Terence Publ. Ltd. (CIWEM), Lavenham.

Diamond, M.L., Gandhi, N., Adams, W.J., Atherton, J., Bhavsar, S.P., Bulle, C., Campbell, P.G.C., Dubreuil, A., Fairbrother, A., Farley, K., Green, A., Guinee, J., Hauschild, M.Z., Huijbregts, M. a. J., Humbert, S., Jensen, K.S., Jolliet, O., Margni, M., McGeer, J.C., Peijnenburg, W.J.G.M., Rosenbaum, R., van de 
Author-produced version of the article published in Water Research, 2017, N¹28, p.412-423.

The original publication is available at https://www.sciencedirect.com

Doi: 10.1016/j.watres.2017.10.039

Meent, D., Vijver, M.G., 2010. The clearwater consensus: the estimation of metal hazard in fresh water. Int. J. Life Cycle Assess. 15, 143-147. doi:10.1007/s11367-009-0140-2

DiGiacomo, P.M., Washburn, L., Holt, B., Jones, B.H., 2004. Coastal pollution hazards in southern California observed by SAR imagery : stormwater plumes, wastewater plumes, and natural hydrocarbon seeps. Mar. Pollut. Bull. 49, 1013-1024. doi:10.1016/j.marpolbul.2004.07.016

Dong, Y., Gandhi, N., Hauschild, M.Z., 2014. Development of Comparative Toxicity Potentials of 14 cationic metals in freshwater. Chemosphere 112, 26-33. doi:10.1016/j.chemosphere.2014.03.046

Ellis, J.B., Mitchell, G., 2006. Urban diffuse pollution : key data information approaches for the Water Framework Directive. Water Environ. J. 20, 19-26. doi:10.1111/j.1747-6593.2006.00025.x

Ellis, J.B., Revitt, D.M., Llewellyn, N., 1997. Transport and the environment: effects of organic pollutants on water quality. J. Chart. Inst. Water Environ. Manag. 11, 170-177.

European Environment Agency, 2012. Copernicus Urban Atlas 2012 [WWW Document]. URL http://land.copernicus.eu/local/urban-atlas\%0A (accessed 7.1.17).

Fantke, P., Huijbregts, M., Hauschild, M.Z., Margni, M., Jolliet, O., McKone, T., Meent, D. van de, Rosenbaum, R.K., 2015. USEtox 2.0 Manual: Inorganic Substances (Version 2).

Gandhi, N., Diamond, M.L., Huijbregts, M.A.J., Guinée, J.B., Peijnenburg, W.J.G.M., van de Meent, D., 2011. Implications of considering metal bioavailability in estimates of freshwater ecotoxicity : examination of two case studies. Int J Life Cycle Assess 16, 774-787. doi:10.1007/s11367-011-0317-3

Gandhi, N., Diamond, M.L., van de Meent, D., Huijbregts, M.A.J., Peijnenburg, W.J.G.M., Guinée, J.B., 2010. New Method for Calculating Comparative Toxicity Potential of Cationic Metals in Freshwater: Application to Copper, Nickel, and Zinc. Environ. Sci. Technol. 44, 5195-5201.

Gasperi, J., Sebastian, C., Ruban, V., Delamain, M., Percot, S., Wiest, L., Mirande, C., Caupos, E., Demare, D., Kessoo, M.D.K., Saad, M., Schwartz, J.J., Dubois, P., Fratta, C., Wolff, H., Moilleron, R., Chebbo, G., Cren, C., Millet, M., Barraud, S., Gromaire, M.C., 2014. Micropollutants in urban stormwater: occurrence, concentrations, and atmospheric contributions for a wide range of contaminants in three French catchments. Environ. Sci. Pollut. Res. 21, 5267-5281. doi:10.1007/s11356-013-2396-0

Gasperi, J., Zgheib, S., Cladière, M., Rocher, V., Moilleron, R., Chebbo, G., 2012. Priority pollutants in urban stormwater: Part 2 - Case of combined sewers. Water Res. 46, 6693-6703. 
Author-produced version of the article published in Water Research, 2017, N¹28, p.412-423.

The original publication is available at https://www.sciencedirect.com

Doi: 10.1016/j.watres.2017.10.039

doi:10.1016/j.watres.2011.09.041

Gilbert, S., Gasperi, J., Rocher, V., Lorgeoux, C., Chebbo, G., 2012. Removal of alkylphenols and polybromodiphenylethers by a bio fi Itration treatment plant during dry and wet-weather periods. Water Sci. Technol. 65, 1591-1598. doi:10.2166/wst.2012.055

Goedkoop, M., Heijungs, R., Huijbregts, M., Schryver, A. De, Struijs, J., Zelm, R. Van, 2009. ReCiPe 2008 A life cycle impact assessment method which comprises harmonised category indicators at the midpoint and the endpoint level - First edition Report I: Characterisation.

Gosset, A., Ferro, Y., Durrieu, C., 2016. Methods for evaluating the pollution impact of urban wet weather discharges on biocenosis : A review. Water Res. 89, 330-354. doi:10.1016/j.watres.2015.11.020

Hadjimichael, A., Morera, S., Benedetti, L., Flameling, T., COROMINAS, L., Weijers, S., Comas, J., 2016. Assessing urban wastewater system upgrades using integrated modeling, life cycle analysis and shadow pricing. Environ. Sci. Technol. acs.est.5b05845. doi:10.1021/acs.est.5b05845

Henderson, A.D., Hauschild, M.Z., Meent, D. Van De, Huijbregts, M.A.J., Larsen, H.F., Margni, M., Mckone, T.E., Payet, J., Rosenbaum, R.K., Jolliet, O., 2011. USEtox fate and ecotoxicity factors for comparative assessment of toxic emissions in life cycle analysis : sensitivity to key chemical properties. Int. J. doi:10.1007/s11367-011-0294-6

Hvitved-Jacobsen, T., Johansen, N.B., Yousef, Y.A., 1994. Treatment systems for urban and highway run-off in Denmark. Sci. Total Environ. 146-147, 499-506. doi:10.1016/0048-9697(94)90275-5

Hvitved-Jacobsen, T., Vollertsen, J., Nielsen, A.H., 2010. Urban and highway stormwater pollution. Concepts and engineering. Taylor \& Francis Group, CRC Press.

ISO, I.O. for S., 2006a. ISO 14040: Environmental Management - Life Cycle Assessment Principles and Framework.

ISO, I.O. for S., 2006b. ISO 14044: Environmental Management - Life Cycle Assessment - Requirements and Guidelines.

JRC European commission, 2011. ILCD Handbook: Recommendations for Life Cycle Impact Assessment in the European context. Vasa 159. doi:10.278/33030

Kim, L.-H., Kayhanian, M., Lau, S.-L., Stenstrom, M.K., 2005. A new modeling approach for estimating first flush metal mass loading. Water Sci. Technol. 51, 159-67. 
Author-produced version of the article published in Water Research, 2017, N¹28, p.412-423.

The original publication is available at https://www.sciencedirect.com

Doi: 10.1016/j.watres.2017.10.039

Lebailly, F., Levasseur, A., Samson, R., Deschênes, L., 2014. Development of a dynamic LCA approach for the freshwater ecotoxicity impact of metals and application to a case study regarding zinc fertilization. Int. J. Life Cycle Assess. 19, 1745-1754. doi:10.1007/s11367-014-0779-1

Lee, J.-H., Bang, K.W., 2000. Characterization of urban stormwater runoff. Water Res. 34, 1773-1780. doi:https://doi.org/10.1016/S0043-1354(99)00325-5

Loubet, P., Roux, P., Loiseau, E., Bellon-Maurel, V., 2014. Life cycle assessments of urban water systems: A comparative analysis of selected peer-reviewed literature. Water Res. 67, 187-202. doi:10.1016/j.watres.2014.08.048

Mailler, R., Gasperi, J., Coquet, Y., Deshayes, S., Zedek, S., Cren-Olivé, C., Cartiser, N., Eudes, V., Bressy, A., Caupos, E., Moilleron, R., Chebbo, G., Rocher, V., 2015. Study of a large scale powdered activated carbon pilot: Removals of a wide range of emerging and priority micropollutants from wastewater treatment plant effluents. Water Res. 72, 315-330. doi:10.1016/j.watres.2014.10.047

Owens, J.B., 1997. Life-cycle assessment in relation to risk assessment: an evolving perspective. Risk Anal. 17, 359-365. doi:10.1111/j.1539-6924.1997.tb00874.x

Pitt, R., Field, R., Lalor, M., Brown, M., 1995. Urban stormwater toxic pollutants: assessment, sources, and treatability. Water Environ. Res. a Res. Publ. Water Environ. Fed. 67, 260-275.

Reap, J., Roman, F., Duncan, S., Bras, B., 2008. A survey of unresolved problems in life cycle assessment. Part 2 : impact assessment and interpretation. Int. J. Life Cycle Assesment 13, 374-388. doi:10.1007/s11367-008-0009-9

Rosenbaum, R.K., Bachmann, T.M., Gold, L.S., Huijbregts, M. a. J., Jolliet, O., Juraske, R., Koehler, A., Larsen, H.F., MacLeod, M., Margni, M., McKone, T.E., Payet, J., Schuhmacher, M., Meent, D., Hauschild, M.Z., 2008. USEtox-the UNEP-SETAC toxicity model: recommended characterisation factors for human toxicity and freshwater ecotoxicity in life cycle impact assessment. Int. J. Life Cycle Assess. 13, 532-546. doi:10.1007/s11367-008-0038-4

Ruel, S.M., Choubert, J., Budzinski, H., Miège, C., Esperanza, M., Coquery, M., 2012. Occurrence and fate of relevant substances in wastewater treatment plants regarding Water Framework Directive and future legislations. Water Sci. Technol. 65, 1179-1189. doi:10.2166/wst.2012.943

Ruel, S.M., Esperanza, M., Choubert, J., Valor, I., Budzinski, H., Coquery, M., 2010. On-site evaluation of the efficiency of conventional and advanced secondary processes for the removal of 60 organic 
Author-produced version of the article published in Water Research, 2017, N¹28, p.412-423.

The original publication is available at https://www.sciencedirect.com

Doi: 10.1016/j.watres.2017.10.039

micropollutants. Water Sci. Technol. 62, 2970-2978. doi:10.2166/wst.2010.989

Schiff, K.C., Allen, M.J., Zeng, E.Y., Bay, S.M., 2000. Southern California. Mar. Pollut. Bull. doi:10.1016/S0025-326X(00)00103-X

SIAAP, 2010. CSO database (2009-2010).

Tabuchi, J.P., Penouel, D., 2014. Bilan annuel 2014 du système d'assainissement SIAAP.

Taylor, G.D., Fletcher, T.D., Wong, T.H.F., Breen, P.F., Duncan, H.P., 2005. Nitrogen composition in urban runoff - Implications for stormwater management. Water Res. 39, 1982-1989. doi:10.1016/j.watres.2005.03.022

Withers, P.J.A., Jarvie, H.P., 2008. Delivery and cycling of phosphorus in rivers: A review. Sci. Total Environ. 400, 379-395. doi:10.1016/j.scitotenv.2008.08.002

Zgheib, S., 2009. Flux et sources des polluants prioritaires dans les eaux urbaines en lien avec l'usage du territoire. Ecole des Ponts ParisTech.

Zgheib, S., Moilleron, R., Chebbo, G., 2012. Priority pollutants in urban stormwater: Part 1 - Case of separate storm sewers. Water Res. 46, 6683-6692. doi:10.1016/j.watres.2011.12.012

Zgheib, S., Moilleron, R., Chebbo, G., 2011. Influence of the land use pattern on the concentrations and fluxes of priority pollutants in urban stormwater. Water Sci. Technol. 64, 1450-1458. doi:10.2166/wst.2011.770

Zgheib, S., Moilleron, R., Chebbo, G., 2008. Screening of priority pollutants in urban stormwater: innovative methodology., in: D. PRATS RICO, University of Alicante, Spain, C.A. Brebbia, Wessex Institute of Technology, UK and Y. VILLACAMPA, University of Alicante, S. (Ed.), Water Pollution IX. pp. 235-244. 